\title{
7
}

\section{Peloidotherapy in Osteoarthritis-Modulation of Oxidative Stress}

\author{
Viorica Marin ${ }^{1}$, Olga Surdu ${ }^{1,2}$, Daniela Profir ${ }^{1}$ and Sibel Demirgian ${ }^{1}$ \\ ${ }^{1}$ Balneal and Rehabilitation Sanatorium of Techirghiol, Constanta \\ ${ }^{2}$ Ovidius" University Constanta, Faculty of Medicine, Constanta, \\ Romania
}

\section{Introduction}

Osteoarthritis is a group of disorders with different etiologies, but similar pathophysiologic changes. In primary osteoarthritis, it is believed that excessive loading cause failure of an otherwise normal joint (Brandt, 1996). The changes eventually involve all of the previously named joint tissues. In particular, the cartilage undergoes breakdown early on, especially in its central areas. Histologically, small tears known as fibrillations and larger tears known as clefts both develop. These defects begin in the superficial zone of cartilage, extend into the transitional zone, and are also propagated by enzymatic breakdown of cartilage. Eventually, large areas of cartilage loss occur, thus essentially exposing the underlying subchondral bone. Other changes within the cartilage include an eventual decline in the ability of the chondrocytes to replicate, an initial increase in the water content of cartilage, a significant reduction in proteoglycan content, a reduction in the size of type II collagen fibers, a diminution of the keratin sulfate concentration, and an increase in the proportion of chondroitin-4-sulfate, consistent with immature cartilage being produced in an attempt to regenerate lost cartilage (Erlich at al, 1996).

Pathogenesis of OA is closely linked to pathogenesis of cartilage degradation. (Maddison, 1998) Oxidative stress, defined as the imbalance between the production and degradation of ROS, is considered to play an important role in mechanism of cartilage degradation. Peroxidation of lipids, spontaneous or catalyzed by metals (iron, copper), and self-maintained by self-catalysis, generates the production of the reactive species of oxygen (ROS). The ROS are aggressive to cells and to macromolecules of cartilage. The ROS produce negative effects inducing oxidation, damage of membranes, modification of proteins and DNA. (Maddison, 1998)

It's well known that ROS have both positive effects - being involved in energy production, phagocytosis, regulation of cellular growth and intercellular signaling, synthesis of some biologically active compounds - and negative effects, initially altering membrane's lipids, tissues proteins, enzymes, carbohydrates and DNA, and finally having a determinant role in the aging process, which characterizes degenerative diseases. Prostaglandins generated by inflammatory reactions contribute to this aggressive phenomenon by hyper activation of macrophages, which generates ROS. (Curcă, 2003-2004)

The cytokines and growth factors produced as part of the changes that occur in OA can have profound effects on cartilage metabolism. The pro-degradative cytokines IL-1 and/or TNF a 
are prime candidates for intervention. How important they are in cartilage pathology remains to be more clearly established in human studies, although a mouse "knockout" approach points to the importance of IL-1a and IL- 6 in cartilage and bone damage. A recent study using the Pond-Nuki dog model of OA has demonstrated that Tenidap (Pfizer Central Research, Groton, CT, USA), a cytokine-modulating drug, can significantly reduce cartilage damage and osteophyte formation, while simultaneously inhibiting the synthesis of IL-1 and the activity of collagenase- 1 and stromelysin-1. (Pool and Webb as cited in Tsokos, 2000)

Certain factors are supposed to have a protective role in the mechanism of cartilage degradation. Superoxide dismutase (SOD), for example, is an enzyme which can be found in different tissues and in the vascular wall. SOD catalyzes superoxide radicals in a neutralization reaction and protects nitrogen monoxide (NO) against inactivation. In the presence of high concentrations of oxygen there is an acceleration of the SOD biosynthesis (Olinescu, 1994). SOD participates directly and indirectly to remove excess of superoxide ions, by inhibiting singlet oxygen and so prevents peroxidation of unsaturated free fatty acids (Salo, 1990). SOD controls the superoxide anions level, thus preventing initiation of the formation reaction of harmful hydroxyl radicals and peroxinitrite (as a result of the reaction between superoxide anions and NO) (Fredovich, 1978).

It was found that certain cytokines, as TNF, or certain lypocarbohydrates, known as stimulating agents of intracellular production of ROS, are also involved in some ROS inactivating mechanisms, from this resulting a fragile balance between production and destruction of ROS. Thus, through an induction mechanism, TNF can stimulate transcription of the Mn-SOD gene. (Pool et. al., 1995)

Gluthatione reductase (GR) is essential for redox cycle of glutathione, which maintains appropriate levels of cellular reduced glutathione. Oxidized glutathione is reduced through a sequence of reactions. (Goldberg \& Spooner, 1983) G-SH is a capital factor in the detoxification of the free radicals, resulted from metabolism or from self-oxidation of polyunsaturated fatty acids in the cell membrane. Glutathione peroxidase reduces hydroperoxide $\left(\mathrm{H}_{2} \mathrm{O}_{2}\right)$ in the presence of G-SH. (Roşoiu \& Verman, 2008)

Reduced glutathione (G-SH) is one of the most important antioxidants from cells, a central component of adaptative system, very sofisticated. (Kidd, 1997) Glutathione exists in the cells both as reduced form (G-SH) and as oxidized form (GSSG), first one being predominant (oxidized form represents less than $10 \%$ from total glutathione). (Kosower, 1978)

G-SH is involved in multiple reactions and processes, is an ideal compound for mantaining intracellular redox potential (Meister, 1994). This involvement is due to the reactivity of -SH group. Unlike -SH groups of other enzymes, which are protected by a polypeptidic chain, those from G-SH or cysteine (thyols with low molecular weight) represent "first" target for free radicals.

G-SH can conjugate NO, forming S-nitroso-glutathione, which is cleaved by tioredoxine system, releasing G-SH and NO. Through its interaction with glutaredoxine and tioredoxine (thyol-proteins), G-SH is playing an important role in regulation of cellular redox homeostasis (Yun-Zhong Fang et al., 2002).

Inside the protective antioxidant mechanism (Wang et al., 1998), G-SH is the substrate for glutathione peroxidase (is used to reduce hydrogen and organic peroxides to water and alcohol), it combines with toxic exogenous and endogenous compounds, reducing disulfidic bridges of the proteins and other molecules and, thus, it mantains reduced state of antioxidative enzymes, glycolitic enzymes and redox status of cells (as a major source of 
thyols), depositing and functioning as transport mean for cysteine. G-SH-transhydrogenases are using reduced glutathione as cofactor for reconvert dehydroascorbate to ascorbate, ribonucleotides to deoxyribonucleotides, etc. G-SH is an efficient detoxifier of ROS (lipidic peroxil radicals, peroxinitrite and hydrogen peroxide), both on direct way and indirect through enzymatic reactions. (Meister, 1991)

Because of its significant reducing potential, G-SH probably contributes to recycle other antioxidants (which were oxidized), as a-tocopherol and carotenoids. (Meister, 1994, 1995)

In physiological conditions blood glucose can reduce molecular oxygen, releasing superoxide ions in the presence of traces of trasition metals $(\mathrm{Fe}, \mathrm{Cu}$ ) and forming cetoaldehides and intermediate oxidation products. Production of free radicals and $\mathrm{H}_{2} \mathrm{O}_{2}$ after self-oxidation process of glucose can determine structural changes of proteins exposed to glucose in vitro.

It has been found that harmful effect due to glucose exposure of albumin is inhibited by catalase, antioxidant defense enzyme, and also by metals chelating agents. It has been suggested that glycosylation and oxidation of proteins are correlated processes, change of the proteins due to glycosylation being associated with peroxidation.

Uric acid is a substance easy to be oxidized and, due to its capacity to capture free radicals, is considered protective factor against continous oxidative aggression to which are exposed majority of body tissues.

"In vitro" experiments showed that uric acid and some purines capture ROS, playing a role in inhibition of peroxidation of polyunsaturated fatty acids, in protection of red blood cells against singlet oxygen attack, in protection of hemoglobin against oxidative stress, in protection of DNA etc. (Olinescu, 1994). The uric acid acts like an antioxidant in the prevention of lipids peroxidation. (Curcă, 2003-2004)

IL-1, although stimulates ROS production (especially NO and products of activated phagocitic cells), in certain conditions can manifest also an indirect antioxidant role, through stimulation of glucose-6-phosphate dehydrogenase activity, followed by an increased production of NADPH, which is essential in glutathion regeneration. (Mehraban, 1998)

Glucocorticoid hormones have indirect antioxidant activity by inhibation of $\mathrm{A}_{2}$ phospholipase, which determines an increase of arahidonic acid available in cells and, therefore, they produce a decrease in quantity of endoperoxides which can attack cell membranes, inhibition of chemotactism for activated cells involved in phagocytosis, inhibition of immune complexes formation, thus reducing ROS formation in active cells during immune response.

Correlated with the activity of endocrine functional harmonization is, also, stimulation of activity of hypotalamic-hypophysis-suprarenalian shaft, resulting in optimisation of plasma levels of: $\beta$-endorphines, ACTH and cortisol.

Neuro-endocrine reactivity, enzymatic and metabolic changes from endocrine glands after mud therapy are different with secretor type of the gland, with functional stage of the gland and are connected with the type of therapeutical application. Under the action of mud there is a harmonical stimulation of all glands, in the direction of increasing enzymatic and synthesis activity, but maintaining each one specificity (Zirra et al., 1964).

The endocrine mechanism is, also, involved in induction of anti-inflammatory effects of mud therapy, due to modulation of activity of hypotalamic-hypophysis-suprarenalian shaft and to endocrine balance, effects which can be seen even after the cure (Modval et al., 1972). 


\section{Techirghiol mud}

Non-conventional therapies using natural factors (as mineral salted water and peloid/sapropelic mud from Techirghiol Lake) are used on empiric basis from ancient times and have unchallenged benefits in rheumatic pathology, but the intimate biological mechanisms of action are yet not known.

Techirghiol therapeutic mud consists in black deposits, rich in colloidal iron hydro sulfur, from the bottom of the salty lake, formed under the action of micro-organisms, from the inorganic substance of the soil, the flora and fauna of the aquatic basin, as the consequence of some biological and chemical transformations, during the biological ages (T,uculescu I., 1965).

\subsection{Peloidogenesis}

The peloidogenesis, as a complex process involving geological, physical, chemical, climatic and biological factors, it is based on organic material which forms tanatozoocenosis and tanatofitocenosis, with an anaerobic evolution, being generated mainly by the Artemia salina crustacean, together with Haliella taurica and the Cladophora vagabunda algae, distributed unequally on the bottom of the lake. In the second phase the iron sulphur is born, the black component of the mud, formed through the activity of the sulphur reduction bacteria, from the combination of the iron with the hydrogen sulphide resulted from the decomposition of the organic materials or, as the case of the iron, from the meteoric waters.

Peloidogenesis runs in three stages:

1. the phase of accumulation and alteration of organic and mineral components. In this stage the origin of mud is established;

2. the sedimentation stage in which the elements are deposited on the bottom of the basin;

3. the physical, chemical and microbiological transformation phase of the flora, fauna and micro-organisms - so called pelogen active agents - convert organic material and minerals in successive stages in the final product. Natural conditions of the lake density, degree of mineralization, biogenic elements content, gas system - all influence the evolution, the dynamics and the microbiological population component. The dying phytoplankton and zooplankton generate organic substances rich in protein and fat. Almost every bacterium participate in this process with enzymatic equipment: dehydrogenase, carboxylase, catalase. The organic remains, the minerals from the bottom of the lake, together with the material transported by water erosion from the lake are transformed into peloidogen material and then peloid. Micro-organisms break down organic substances and mineralize them and enrich mud with their waste products: vitamins (C, B1, B2, B12), biostimuline, auxinic, biotin, nicotinic acid, carotenoids, substances such estrogenic phenols group. In the liquid phase carbohydrates are oxidized, proteins are decomposed, the fatty acids are desaturated resulting the acetic, formic and valerian acid. Bacteria are present and involved in the "life" of mud, not only in the training forming stage, but also afterwards when they help maintain the biological balance and self-purification of mud and and water basins - a phenomenon called bacteriophagy. (Teleki, 1984; Banciu, 1996) Micro-organisms grow in an environment represented by protein substances, pectin, soluble carbohydrates, soluble proteins, etc. The fauna and flora, as well as the microfauna and microflora present in the mud are: protozoa, copepods, cladocers, hemipters, diptych, beetles, hydrofilids, rotifers, diatomaceous, chlorofycee, cyanophycee. Peloidogenesis is a 
complex phenomenon that takes thousands of years and never stops, being conditioned by the hydro-geological characteristics of the area and elements influenced by physicochemical, biological and microbiological (enzymatic micro equipment: catalasis, oxidasis, reductasis, gelatinasis), each ecosystem and each mud peloidogen resulted is unique. (Diaconescu, 1973) The rhythm, the amount and evolution of peloidogenesis at a certain time may be determined by placement and periodic control of sedimentation on the bottom platform in selected areas for this purpose. It is in fact an analysis of current status of deposit. The mud is mineralizing slowly in time, aging, a phenomenon called diagenesis. (Teleki, 1974). Peloids formation and maturation are slow and permanent processes reflected in their chemical composition. Comparison of some chemical compounds of peloids at different intervals and in certain circumstances allows the assessment of the evolution and maturation of the mud. Ratio of the crystal structure and structure of calcium-magnesian clay is the coefficient incarbonization of peloid, showing maturation stage. Its value ranges between 0.003 and 2.1. Ratio of sulphates and carbonates from the mud reflects its age: increased sulfate content is characteristic to "young" peloids, while carbonates characterise "mature, old" peloids. The peat age is appreciated by the ratio of humic acids / cellulose, an increased value at around 2.8 - indicating a mature peat.

The mud from the Techirghiol lake is very well hydrated, with a high content of mineral substances and a lower content of organic substances. It has a great capacity of absorption of the ions $\mathrm{Ca}, \mathrm{Ng}, \mathrm{K}$ and $\mathrm{Fe}$, which is very important for therapeutic effects, because of the mobilization of these ions in the organism.

The specificity of the therapeutic mud is given by the primary factor $\left(\mathrm{H}_{2} \mathrm{O}\right.$ of the lacustrine basin), and by the mineral and organic substances.

In time the mud quality depends on the balance of the three elements and on the uniformity of the peloidogenesis process.

\subsection{Physical characteristics of Techirghiol mud}

Techirghiol mud is an alkaline mud, $\mathrm{pH}$ is 8,2 .

Density value is $1,283 \mathrm{~g} / \mathrm{cm}^{3}$ and is determined by the nature of the elements which compose it.

Thermopexy is the capacity of absorption, retention/storage and release caloric energy (gives therapeutic value to the mud), and is the most important feature, along with spreading capacity; it is determined by the Denade.

Plasticity is the feature of the mud to change its form under the action of an external force in time. The coefficient of flowing is $43-56 \%$ (medium). (Tuculescu I., 1965)

The spreading capacity depends on the size of the mud granules and for Techirghiol mud is $99.57 \%$. The spreading of the mud is the capacity of fine particles $(0,1 \mathrm{~mm})$ to spread uniformly in the tube water and to adhere tightly to the tegument (Teleki et al, 1984).

\subsection{Chemical characteristics of Techirghiol mud}

The chemical composition of Techirghiol mud consists in: water, mineral substances, organic substances.

The water represents over $70 \%$ from the mud's components and it is found as hydrating and colloidal water. 
Mineral substances: insoluble salts (calcium sulfates and carbonates, silicates); clay component: $\mathrm{SiO}_{2}$ and small quantities of oxides; the colloidal component: iron hydro-sulfur, iron and aluminum silicates, organic-mineral complexes.

Organic substances: from the fito-zooplakton of the aquatic basin, from vegetal remains and decomposed animals are represented by carbonhydrates (cellulose and hemicelluloses), humic and humic acids, lipids, proteins and amino-acids, the B group vitamins, nicotinic acid, a bituminous component which contains estrogen-like active substances. According to the standards of National Research Institute of Rehabilitation and Physical Medicine and following the procedure of Romanian Farmacopee for natural products analysis, the report on Techirghiol sapropelic mud is shown in table 1. (Surdu, 2006)

\subsection{Methods of mud application}

Known and used from the antiquity, mud's ways of applications are still the same: cold ointment (following the antique egyptian method), thermoneutral mud bath and hyperthermic mud wrapping/pack.

Warm salted bath can be performed on a daily basis, as a single major procedure of hydrotherapy, or every other day alternatively with mud application or with warm bath containing herbal extracts. Prescribed temperature for salted bath must belong to the neutral field; it means around $37,5^{\circ}-38^{\circ} \mathrm{C}$. For hydro-kineto-therapy the water is heated up to $35^{\circ} \mathrm{C}$ (Lupu, 1956; Surdu, 2006).

Cold mud ointment is a therapeutic complex, which consists from hot-cold contrast. Cold mud ointment is performed in the summer time, on a specially designed beach, where fresh extracted mud is brought daily or every other day. After a 15-20 minutes sun exposure, the patient applies on the whole body surface a mud layer of 1-1. $5 \mathrm{~cm}$ thick. Drying of the mud on the skin takes 15-30 minutes, depending of the environment temperature. The patient enters into the lake water in order to remove dried mud, and then performs active movements of all body segments. In the end of the procedure the patient takes a tap water shower. Duration of sun exposure is increasing daily (from 5-10 minutes first day up to 3040 minutes in the end of the cure), as well as the number of lake immersions. The number of mud applications per day is constant. Meanwhile the cure one must take only one mud application per day. (Teleki et al., 1984)

Thermoneutral mud bath is prepared using $10 \mathrm{~kg}$ of mud in 120-150 L of salted water from the lake. Application temperature is around $37.5^{\circ} \mathrm{C}-38^{\circ} \mathrm{C}$, thermoneutrality point for mud being at $38^{\circ} \mathrm{C}$. The mud bath takes $20-25$ minutes and temperature is maintained almost constant adding warm water after half the time. Once the time expired, the patient takes a warm shower in order to remove the mud from the skin and a quick cold shower in order to avoid systemic vasodilatation. General mud bath is indicated once every two days, alternatively with salted warm bath (in the swimming pool or in the tube) or herbal extracts warm bath. (Onose, 2000)

Hot mud general packing is prepared using $10-15 \mathrm{~kg}$ of mud heated at $42^{\circ} \mathrm{C}-45^{\circ} \mathrm{C}$. The mud is smeared all over the body surface, from neck to toes. The patient is covered with a sheet and a blanket, gets a cold compress on his forehead in order to avoid a strong vasodilatation of cerebral vessels and remains like that for 30 minutes. After time expires, the mud is washed with a warm shower. The procedure ends with a short cold shower, in order to prevent irreversible dilatation produced by heat. Mud packing is performed once two days, alternative with a warm salted bath or with a bath containing herbal extracts. (Surdu, 2006; Onose, 2000) 


\begin{tabular}{|c|c|c|c|}
\hline CRT. NR. & $\begin{array}{c}\text { PHYSICAL CHEMICAL } \\
\text { PARAMETERS }\end{array}$ & VALUES & OBSERVATIONS \\
\hline \multicolumn{4}{|c|}{ GLOBAL CHEMICAL COMPOSITION ( G \% ) } \\
\hline 1. & Humidity (water) & $71,24 \mathrm{~g} \%$ & \multirow{4}{*}{$\begin{array}{l}\text { Reported in whole } \\
\text { humid mud }\end{array}$} \\
\hline 2. & Volatile substances & $8,4 \mathrm{~g} \%$ & \\
\hline 3 & Total mineralisation & $20,36 \mathrm{~g} \%$ & \\
\hline & TOTAL $=$ & $100,00 \mathrm{~g} \%$ & \\
\hline \multicolumn{4}{|c|}{ ORGANIC SUBSTANCES ( G\%) } \\
\hline 1 & Total humic substances & $0,9551 \mathrm{~g} \%$ & \\
\hline 2 & Proteins & $1,112 \mathrm{~g} \%$ & \\
\hline 3 & Fats+ waxes+ resins & $\begin{array}{l}1,612 \mathrm{~g} \% \\
\text { (ether extract) }\end{array}$ & \\
\hline 4 & cellulose & $0,4834 \mathrm{~g} \%$ & $\begin{array}{l}\text { Reported in whole } \\
\text { humid mud }\end{array}$ \\
\hline 5 & bituminous & $\begin{array}{l}3,209 \mathrm{~g} \% \\
\text { (benzene-alcohol extract) }\end{array}$ & \\
\hline 6 & Pectins + carbohydrates & $\begin{array}{l}2,213 \mathrm{~g} \% \\
\text { (water extract) }\end{array}$ & \\
\hline \multicolumn{4}{|c|}{ MINERAL CONTENT (PPM/ G\%) } \\
\hline 1 & Iron & 3448,332 / 0,3449 ppm / g\% & \multirow{7}{*}{$\begin{array}{l}\text { Reported in whole } \\
\text { dry mud }\end{array}$} \\
\hline 2 & Calcium & 32205,91 / 3,2206 ppm / g\% & \\
\hline 3 & Sodium & $44608,94 / 4,4609$ ppm / g\% & \\
\hline 4 & Kalium & 18771,12 / 1,8771 ppm / g\% & \\
\hline 5 & Manganese & $270,022 / 0,027 \mathrm{ppm} / \mathrm{g} \%$ & \\
\hline 6 & Magnesium & 39544,64 / 3,9545 ppm / g\% & \\
\hline 7 & Silicates & / 13,82 ppm / g\% & \\
\hline \multicolumn{4}{|c|}{ INDICATORS OF PELOIDOGENESIS (G\%) } \\
\hline 1 & Organic carbon ( C ) & $1,313 \mathrm{~g} \%$ & \multirow{3}{*}{$\begin{array}{l}\text { Reported in whole } \\
\text { humid mud }\end{array}$} \\
\hline 2 & Organic azoth ( N ) & $0,129 \mathrm{~g} \%$ & \\
\hline 3 & Ratio C / N & $10,18 \mathrm{~g} \%$ & \\
\hline \multicolumn{4}{|c|}{ SULFUR COMPOUNDS (G\%) } \\
\hline 1 & Total $\mathrm{H}_{2} \mathrm{~S}$ from wich & $0,1257 \mathrm{~g} \%$ & \multirow{3}{*}{$\begin{array}{l}\text { Reported in whole } \\
\text { humid mud }\end{array}$} \\
\hline 2 & $\mathrm{H}_{2} \mathrm{~S}$ free & $0,0449 \mathrm{~g} \%$ & \\
\hline 3 & $\mathrm{H}_{2} \mathrm{~S}$ linked & $0,0808 \mathrm{~g} \%$ & \\
\hline \multicolumn{4}{|c|}{ GLOBAL PHYSICAL CHARACTERISATION } \\
\hline 1 & $\mathrm{pH}$ & 8,2 & \multirow{2}{*}{$\begin{array}{l}\text { determined in whole } \\
\text { humid mud }\end{array}$} \\
\hline 2 & Density $\rho_{20}$ & $1,283 \mathrm{~g} / \mathrm{cm}^{3}$ & \\
\hline 3 & Dry substance (DS) & $28,73 \mathrm{~g} \%$ & \\
\hline 4 & Changeable basis & $47,6 \mathrm{mEq} / 100 \mathrm{~g}$ mud & $\begin{array}{l}\text { Reported in whole } \\
\text { humid mud }\end{array}$ \\
\hline 5 & $\begin{array}{l}\text { Spread index of mud } \\
\text { Particules`diameter }(\mathrm{mm})\end{array}$ & \begin{tabular}{|l|l|}
$\mathrm{mm}$ & $\%$ \\
0,315 & 0,16 \\
0,200 & 0,30 \\
0,100 & 1,68 \\
0,090 & 0,60 \\
0,080 & 3,88 \\
0,063 & 19,6 \\
0,056 & 7,28 \\
0,050 & 5,90 \\
0,045 & 40,80 \\
0,040 & 9,92 \\
Less than & 9,86 \\
0,040 & \\
\end{tabular} & $\begin{array}{l}\text { Determined in whole } \\
\text { dry mud }\end{array}$ \\
\hline
\end{tabular}

Table 1. Physical-chemical characterisation report on Techirghiol sapropelic mud 
Mud collection is performed from the central area of the lake, where there are three deposits ("islands") of therapeutic mud. Here the mud is settled uniformly, without any foreign material, having a characteristic aspect: black, shiny, unctuous, very plastic, with a very fine granular structure and a specific smell. This is the area from where mud is extracted for over one hundred years and used in all sanatoriums on the seaside (Diaconescu et al., 1973; Tuculescu, 1965). For mud collection is necessary a claw bucket mounted on a boat. From the boat mud is absorbed with a pump and loaded into a tank, which transports it inside the treatment area, where is deposited in special boilers provided with electric heating and mixing systems. Mud shelf life in the bunker is 4-6 days. From here is provided also the mud for cold ointments in the summer time. After collection from the lake, mud is transported to the solarium, where is stored in the recipients outside (Surdu et al., 2005).

\subsection{Physical mechanisms of mud action}

The thermal factor: effects are according to the temperature of the mud - the warm application $\left(38^{\circ} \mathrm{C}\right)$ determines pain relief, decrease of muscles contracture and has antiinflammatory effects; higher temperature application has immune-stimulating, tonic, cardiovascular overwork effects.

The physical component of the action of mud on the human body refers to the existing mechanical and thermal conditions during application. Mud thermotherapy is possible due to mud's properties to maintain temperature. This capability of mud allows its application at higher temperatures than body's temperature. There is a slow transfer of heat stored in the mud, allowing the body to take over an amount of this heat. Temperature affects living systems starting with the fundamental biophysics and molecular energy levels up to the most complex systems functionally speaking. The temperature influences the structure of cell membranes and protoplasmatic parts - non-covalent bonds (ionic, van der Waals, hydrogen bridges), the number of hydrogen bridges from the helix structure of nucleic acids and proteins, the phospholipids mezomorphysm, the state of lamellar or hexagonal phase of membranes, the state of oil and fatty acid chains. The temperature continues to be the one that influences functions and biochemical reactions in the membrane and cytosol - the mobility of membrane receptors (with implications in the defense processes as for instance, the formation of lymphocyte cap), plasmalemma vesicles formation, hydrophobic binding of insulin receptors, activitation of adenilcyclasis, enzymes synthesis, the presence / appearance or not of isoenzymes, the rate of diffusion, the Donnan equilibrium, oxygen consumption, etc. The temperature influences the bioenergetic cellular activity, multiplication, defense, various functional control and protection systems. For all biological processes, the temperature is one of the most important conditions for ideal development. For the vast majority of warm-blooded organisms the optimal functional thermal point is located around the temperature of $39^{\circ} \mathrm{C}+/-1^{\circ} \mathrm{C}$, but most organisms live below this heat value. The environmental temperature to which the request of thermoregulatory mechanisms is minimum represents the neutral area, that is to say the individual has no heat needs. The thermal field of peloidotherapy begins with cold application and goes to hyperthermia, each type of application having typical therapeutic effects and consequences. The application of cold mud is a complex heat treatment which consists of successive contrast hot-cold, developed in two phases: the first phase includes sun exposure on the solarium hot sand / beach for about 20 minutes and anointing with mud, and the second phase involves sun exposure for about 30 minutes in order to install a mild 
hyperthermia, followed by a lake bath/cold shower. Under the direct influence of thermal contrast and indirect influence of the information from thermal receptors, the effector function of peripheral variable heat flow is enhanced by modulating local, partial and finally general circulation and by optimizing the release of self-amplification cell eicosanoids factors. Recent studies on the thermodynamics of soft tissue during cold applications reveal hemodynamic changes as a substrate of thermal changes occurring during application. The muscle tissue is the source of skin reheating after cold application and, even it does not suffer significant decreases in temperature during application, 40 minutes after the end of application it cools, along with the increasing of skin and subcutaneous tissue temperature. (Enwemeka et al., 2002). Thermogenesis and thermolysis reactions are obtained through contrasting therapy, optimizing thus the thermal homeostatic balance. The activation of these programs, their hierarchy, the increasing of the anticipation and reply capacity (feed before) lead to increased performance of adaptive response of the body as a result of an improvement in balance and finally warm-blooded overall body homeostasis. (Andrieş, 1994) Thermal neutrality is the temperature which gives no termoestesic sensation and reduces / maintains the minimizes heat setting processes. This temperature is around $34-35^{\circ} \mathrm{C}$ for water and $38^{\circ} \mathrm{C}$ for mud. During the thermoneutral mud bath the body is subject to mechanical forces according the laws of physics stated by Archimedes (body weight loss equal to the weight of displaced liquid) and Pascal (the reduction of chest, abdomen and limbs circumferences in relation to the immersion due to pressure transmission in a liquid in all directions with the same intensity). So, besides from the thermal factor there is also a mechanical acting. During the immersion in mud bath gravity and termoestesic information are reduced, and therefore cortical activation is minimal, allowing stabilization of humoral and neuro-endocrine homeostasis stability in neuropsychological and biological parameters of comfort. While reducing the gravitational and thermal information, information from interoceptors begin to grow, especially from the baroreceptors stimulated by the new hemodynamic conditions and therefore neuroendocrine cardiac depressant processes activate (Bainbridge effect), the Henry-Gauer reflex of inhibiting secretion of vasopressin sets in with its natural consequence of lowering blood pressure. The prolongation of the immersion in the bath over 20 minutes leads to thermoneutrality, mostly because of some endocrine-regulating processes, which secrete a humoral natriuretic and diuretic factor ANF (Atrial natriuretic factor), related with a feedback loop by vasopressin. The vasopressin stimulates the secretion of ANF, which in turn inhibits the secretion of vasopressin. Thus, a thermoneutral bath lasting for 30-40 minutes can lead to blood pressure decrease with about 30\%. (Andrieş, 1994) Because its thermoregulatory qualities, mud can be used in the treatment of hyperthermia. Hyperthermia appears when core temperature increases over $37.3^{\circ} \mathrm{C}$ by passive heat input. Increased temperature in central area and further in peripheral thermoregulatory area - the poikiloterm area (extremities) - has the following consequences: increased migration of leukocyte inhibitory factor (LIF), macrophag inhibitory factor (MIF), the activation of lymphoblastic transformation, the stimulation of platelet activity of fibrinolytic system, the increase in interferon synthesis. Not only functional, but also structural changes take place under the influence of temperature increase, such as formation of lymphocyte caps (capping) of plasmalemma vesicles, etc. Cellular defense and immunity are two areas with particular benefits from hyperthermia. The central serotonin core system is activated at a temperature of $38-39^{\circ} \mathrm{C}$ (which inhibits the activity of the sympathetic nervous system at central level), so it stimulates hypothalamic-pituitary system (with ACTH, endorphins, melanotropin release) and synthesis of prolactin. 
However, under the action of mud baths, the whole body temperature is "baffled", all devices and systems "work transitory" in a regime requiring all means of antientropic control for maintaining homeostasis of internal environment (Andrieş, 1994). In conclusion, we should bare in mind that there are few effects under the action of the heat factor of mud application.

\subsection{Chemical mechanisms of mud action}

The humic acid and the humic salts are ions changeable substances, influencing ions 'passage between skin and bath medium. They also modify the status of some skin enzymes such as: cytochrome-oxidase, ATP-ase, and alkaline phosphatase, that become active within skin. The skin $\mathrm{pH}$ modification increase the permeability at this level. (Teleki et al., 1984). Among the chemical components with proven and / or recognized action there are: the humic component, the estrogen bitumen component, the hydrogen sulfide, various ions, biologically active substances produced by microbiological flora and fauna, etc. Because of their chemical composition, peloids acts pharmacodynamically by ion exchange with skin or mucous membranes that come into contact with. Ion exchange capacity is determined mainly by colloidal substances: humic acids, hydrosulfuric colloidal iron. Sorption peloids capacity was calculated using the Mehlich-Dowexhil method, which expresses the ion exchange degree in $\mathrm{mEq} \%$. For example at $20^{\circ} \mathrm{C}, 1 \mathrm{~kg}$ of Techirghiol mud retains $5.48 \mathrm{~g} / \mathrm{l}$ calcium, $11.50 \mathrm{~g} / \mathrm{l}$ magnesium and $9.34 \mathrm{~g} / \mathrm{l}$ iron. Ions in mud bath selectively penetrate the skin, depending on the electrical charge of the skin and the permeability of skin is increased by the environmental temperature. Soluble elements from the mud's soluble phase participate in the exchange between the skin and mucous membranes, and more intense is the exchange, more diluted is mud. In addition, a comparative study was made in order to compare effects of concentrated mud baths (70-150 kg mud / water in a bath tube with 3001 chlorosodic water from lake Techirghiol) versus diluted mud baths (1 kg mud in a valve with the same amount of water). The overall effects of treatment with diluted mud baths were superior to those obtained with concentrated mud baths and confirmed statistically. The soluble elements transfer from the liquid components of mud, through epithelial cells, is activated by an "enzymatic barrier" represented by cytochrome, alkaline phosphatase and ATPase. In addition, if salted water (such as the water from Techirghiol lake), is combined with mud to prepare mud bath, crystals and salts remain on the skin as a "salt sheath", and along with the hygroscopic action of $\mathrm{NaCl}$ stimulate the nerve endings. The crystals on the skin surface retain water from atmosphere, thus making possible different osmotic exchanges at the skin level compared with basal needs. Skin acid $\mathrm{pH}$ gives permeability only for cations. A change in $\mathrm{pH}$ increases the permeability of skin also for anions. The alkaline hot mud baths change the skin electronegatively, while the acid mud baths - the only acid mud found in Romania is in Stobor - change the skin electropositively. Some of the ions leave the skin and pass into the bath water. Thus, there is a double passage of ions that alter the excitability of skin and skin reflexes starting points. The chemical composition of environment influences mud bath and hydromineral balance of the body by various ions which can either accumulate $\left(\mathrm{K}^{+}, \mathrm{Br}^{+}, \mathrm{Mg}^{2+}\right)$, or they can favour the retention / removal of elements such as chlorides and carbonates of sodium, by increased $\mathrm{Ca}$ and $\mathrm{P}$ retention in the body, or by established inter-relationships between $\mathrm{Cl}^{-}, \mathrm{Br}^{-}, \mathrm{K}^{+}, \mathrm{Na}^{+}, \mathrm{Ca}^{2+}, \mathrm{Mg}^{2+}$. The action of ions can be seen as qualitative exchanges in the body's mineral composition by replacing certain elements with others that are in excess and by accumulation those with low level. The humic substances have antihyaluronidasic 
activity, while variations in fibrinogen and fibrinolytic activity are neither parallel nor significant. Antihialuronidazic activity of humic acids from mud has been demonstrated in vitro. (Pizzoferrato, 2000) The thermal bath at $35^{\circ} \mathrm{C}$ does not have this action, which led to the conclusion that inhibitory action is due to mud and not to its thermal effect. Histoenzymatic studies at various levels (skin, internal organs, endocrine glands) revealed differences of enzyme substrates in relation to different type of mud application. In this context, it is insufficient to mention only the enzymatic activity of mud. We can rather talk about the modulating role upon enzymatic that some of mud's components exercise. We have already mentioned the activation of enzyme systems as well as the effects of skin temperature on metabolic reactions. Hydrogen sulfide produces skin hyperthermia even in lower temperatures of mud, it enhances the activity in histaminasis tissue and increases histaminopexic serum activity with the effect of desensitizing the body. Estrogen-active elements from the bitumen component are highlighted through biological tests that revealed the estrogenic action of mud. The microbiological component of mud produces besides vitamins, growth factors, auxine - biogenic stimulators - biotine - a sulphoglicolipid with antiinflammatory action. (Tolomino et al., 1999) The list of the substances / active ingredients in mud is not complete and can not be completed. Each mud and its aquatic environment of formation and existence are like living organisms in a continuous dynamics. Chemical composition of mud is a "puzzle", that can have all the pieces but not yet arranged for us to create the image of the possibilities of action.

The peloidotherapy produces an harmonic stimulation in all the glands, namely increasing the enzymatic activity and the glandular synthesis, and keeping the specificity of each gland, a persistent and post-cura stimulation. There is a persistent after treatment stimulation the hypothalamus -hypofisal -suprarenalian shaft, emphasized by the increasing of A.C.T.H. secretion, an improvement of vasomotor reactions and of the thermo regulation process.

\section{Conclusion}

Evaluation of anti-inflammatory potential of sapropelic mud from Techirghiol in patients with osteoarthritis, through assessment of oxidative stress markers, was confirmed by a statistically significant increase of SOD level and by a decrease of reduced glutathione level under the action of mud treatment. The increase of SOD level after mud treatment suggests a positive response of the body, considering the positive role of enzyme in ROS neutralization and NO inactivation. The levels of glutathione reductase, uric acid or blood glucose, protective factors in oxidative stress balance, haven't been influenced by mud treatment. This conclusion emphasizes the protective character of mud therapy on oxidative stress, the enzymes with positive effect on this metabolism increasing, as in SOD case, or maintaining in normal range, as in GR and TAS case (Marin et al., 2009)

Assessment of stress hormones activity showed an optimization of plasma cortisol level and revealed, also, a stimulation of hypotalamic-hypophysis-suprarenalian shaft, sustained by significant increase of tyroid stimulating hormone (TSH) level. The increase of TSH level, for both warm and cold mud applications, shows a stimulation of hypotalamic-hypophysissuprarenalian shaft under the action of mud. So, the endocrine mechanism is involved, also, in induction of anti-inflammatory effects of mud therapy, by modulating of activity of hypotalamic-hypophysis-suprarenalian shaft and by general balancing of endocrine system, effects that last probably even after cure (Marin et al., 2007). 
Assessment of anti-inflammatory potential of sapropelic mud from Techirghiol in patients with osteoarthritis, by measuring inflammatory cytokines levels, has confirmed this effect through an important decrease of TNF- $\alpha$ and IL-6 values in patients which had initially peak values. Also, it has decreased statistically significant the level of receptors for TNF-a, sCD27, fact that sustains the decrease of TNF-a level. (Marin et al., 2011).

Increase of oxygen intake in peripheral blood by opening arterial-venous shunts and improving circulation to peripheral tissues, and osteoarticular tissue also. It was demonstrated the strong growth and consistent within 24 hours of oxygen saturation in the peripheral blood $\mathrm{SO}_{2} \%$, partial pressure of oxygen at this level $\mathrm{pO}_{2}$, the oxygen-binding capacity of the hemoglobin $\mathrm{O}_{2} \mathrm{CAP}$ and oxygen content of hemoglobin $\mathrm{O}_{2} \mathrm{CT}$. A lower amount of lactate in the peripheral blood and a constant blood $\mathrm{pH}$ and carbon dioxide partial pressure suggests an improvement in peripheral tissue metabolism through increased intake of oxygen and nutrients. (Marin et al., 2011).

The obtained results, confirming anti-inflammatory action of mud, should recommend mud as a therapeutic solution for osteoarthritis treatment.

\section{References}

[1] Andrieş, V. (1994). Note de curs, Medicina Fizică, Balneoclimatică şi Kinetoterapie, Universitatea Carol Davila Bucureşti, Editura medicală, Partea I, 37-38, 65-66, 72, 75-77.

[2] Banciu, M. (1996). Balneofizioterapie generala si concepte moderne de recuperare, Editura Mirton, Timisoara,.5-12.

[3] Curcă, D. (2003-2004). Efectele benefice şi cele malefice ale speciilor de oxigen reactive şi radicalilor liberi la animale, Lucrări ştiințifice U.Ş.A.M.V.B. Seria C, vol. XLVI-XLVII.

[4] Diaconescu, L. E.; Anghelopol, C.; Dumitrescu, C. (1973). Studiul comparativ al microelementelor: $\mathrm{Zn}, \mathrm{Cu}, \mathrm{Co}, \mathrm{Ni}$, Ti, V, Mo şi Cr din apa Mării Negre a litoralului românesc pe patru niveluri; apa lacului şi extrasului de Techirghiol, în Apele minerale şi nămolurile terapeutice din Republica Socialistă România , Editura Medicală Bucureşti, 11, 517-526.

[5] Enwemeka, C.S.; Allen. C.; Avila, P.; Bina, J.; Konrade, J.; Munns, S. (2002). Soft tissue thermodynamics before, during, and after cold pack therapy; Med Sci Sports Exerc. January, 34(1), 45-50.

[6] Fredovich, I. (1978). Superoxide dismutases: defence against endogenous superoxide radical,. Ciba Foundation Symposium. 65, 77-93J

[7] Goldberg, D.; Spooner, R. (1983). Glutathione reductase, In Bergmeyer H.U., Ed. Methods in enzymology , Vol 3, 258-265, isbn 3-527-26041-2, Basel: Verlag Chemie.

[8] Kidd, M., (1997). Glutathione: Systemic Protectant against Oxidative and Free Radical Damage, Alternative Medicine Review, Vol.2, nr.3, 155-156.

[9] Kosower, N.; Kosower, E. (1978). The glutathione status of cells, International Review of Cytology, 54, 109-156.

[10] Lupu N. Gh. (1956), Medicină internă, volumul I, Semiologie şi terapeutică generală, Editura Medicală Bucureşti, Capitolul balneologie - prof. Dr. E. Moraru., 378.

[11] Maddison, P., Isenberg, D., Woo, P., Blass, D., (1998). Oxford text book of Rheumatology, isbn 978-019-850-948-6, Ed. Oxford University Press 2 edition.

[12] Marin, V.; Profir, D.; Surdu, O.; Rosoiu, N. (2007), Therapeutically effects of Techirghiol sapropelic mud in oxidative stress at patients with osteoartritis, FEBS Journal, Volume 274, Supplement 1, Julay 2007, pp.1-378, 32nd FEBS Congress, "Molecular Machines", Vienna, Austria, C4-76, 213. 
[13] Marin, V.; Profir, D.; Ionescu, E. V.; Başa, M.; Roşoiu, N.; (2009). Effects of Techirghiol mud in oxidative stress at patients with osteoarthritis, Archives of the Balkan Medical union, 44, 3, 196-200.

[14] Marin, V.; Profir, D.; Surdu, T. V.; Roşoiu, N. (2011). Variation of Serum Level of Proinflammatory Cytokines after Mud Therapy in Patients with Osteoarthritis, Archives of the Balkan Medical Union, 45, 1, 69-74.

[15] Marin, V.; Profir, D.; Roşoiu, N.; Petcu, L. (2011). Evaluation of Blood Gases Pressure in Patients Treated with Sapropelic Mud of Techirghiol, Archives of the Balkan Medical Union, 45, 1, 69-74.

[16] Mehraban, F.; Lark, M.; Ahmed, F.; Xu, F.; Moskowitz, R. (1998). Increased secretion and activity of matrix metalloproteinase- 3 in synovial tissues and chondrocytes from experimental osteoarthritis, Osteoarthritis Cartilage, 4, 286-294.

[17] Meister, A., (1991). Glutathione deficiency produced by inhibition of its synthesis, and its reversal; applications in research and therapy, Pharmacology and Therapeutics, 51, 155-194.

[18] Meister, A. (1994). Minireview: Glutathione-ascorbic acid antioxidant system in animals, Journal of Biology and Chemistry, 269(13), 9397-9400.

[19] Meister, A. (1994). Glutathione, ascorbate, and cellular protection, Cancer Research (Suppl), 54, 1969S-1975S.

[20] Meister, A. (1995). Glutathione metabolism, Methods in Enzymology, 251, 3-7, 61.

[21] Modval, M.; Benetato, V.; Constantinescu, I.; Popescu ,V.; Popa, M.; Bălăceanu, V. (1972). Acțiunea aerohelioterapiei asociata cu ungeri de nămol rece asupra funcției hipotalamo-hipofizare şi suprarenalelor la bolnavii artrozici, Studii şi cercetări de balneologie şi fizioterapie, vol. XI, Ed. Medicală Bucureşti. pag. 148 -149.

[22] Olinescu R., 1994, Radicali liberi în fiziopatologia umană, Ed. Tehnică Bucureşti.

[23] Onose G. (2000). Aspecte conceptuale actuale ale prescripțiilor balneare hidro-termoterapeutice la vârstnici, Raport la Conferința Națională cu participare internațională Actualități şi perspective în gerontologie şi geriatrie la cumpăna dintre milenii, 31 mai-2 iunie, Otopeni, Bucureşti

[24] Pizzoferrato, A.; Garzia, I.; Cenni, E.; Pratelli, L.; Tarabusi, C. (2000). Beta - endorfinele si hormonii de stres la pacientii artrozici tratati cu impachetari calde cu namol; Minerva Med Oct; 91 (10), 239-45.

[25] Poole, A.R.; Rizkalla, G.; Ionescu, M.; Reiner A.; Brooke, E.; Rorabeck, C. (1995). Osteoarthritis în the human knee: dynamic process of cartilage matrix degradation, synthesis and reorganization in Joint Destruction, in Arthritis and Osteoarthritis, Birkhaeuser, Basel, 10, 3-13.

[26] Roşoiu, N.; Verman, G.I. (2008). Biochimie clinică, Editura Muntenia, Constanța.

[27] Salo, D.C.; Pacifici, R.E.; Lin, S.W.; Giuilivi, C.; Davies, K.J. (1990). Superoxide dismutase undergoes proteolysis and fragmentation following oxidative modification and inactivation, Journal of Biological Chemistry, 15, 265, 11919-27

[28] Surdu, O.; T,ebrencu, C.; Marin, V.; Profir, D. (2005). Studiul variației în timp a compoziției chimice a nămolului sapropelic de Techirghiol de la extracție până la finalul aplicației terapeutice, Revista de Recuperare, Medicina Fizica si de Balneologie, nr. 3 -4, pp. 52

[29] Surdu, O. (2006). Evaluarea factorului chimic de acțiune al nămolului sapropelic de Techirghiol, 18-19, isbn 978-973-591-520-9, Ed. Gramar, Bucureşti

[30] Teleki, N.; Munteanu, L., Stoicescu, C.; Teodoreanu, E.; Grigore, L.; (1984). Cura balneoclimatica în România, 50-52, 76-82, Editura Sport-Turism, Bucureşti

[31] Tolomino C, Ceschi-Berrini C, Moschin E, Galzigna I. (1999). Colonization by diatoms and antirheumatic activity of thermal mud, Cell Biochem Funct. Mar; 17(1), 29-33. 
[32] Tsokos, G.C. (2000). Principles of molecular rheumatology, Ed. Humana Press Inc., New Jersey.

[33] T,uculescu, I. (1965). Biodinamica lacului Techirghiol; Biocenozele şi Geneza nămolului, Ed. Academiei Republicii Socialiste România, 120.

[34] Wang, L.; Yeh, C.; Hou, M.; Tsai, S.; Lin, S.; Hsiao, J.; Huang, J.; Wu, S.; Hou, L.; Ma, H.; Tsai, L. (1998). Superoxide anion radical, lipid peroxides and antioxidant status in the blood of patients with breast cancer, Clinica Chimica Acta, 361(1-2), 104-111.

[35] Yun-Zhong, F.; Sheng, Y.; Guoyao, W. (2002). Free radicals, Antioxidants and Nutrition, Nutrition, Elsevier Science Inc., 18, 872-879.

[36] Zirra, A. M.; Voicu, A.; Comnoiu, M.; Stratulat, L.; (1964). Modificări histochimice în glandele endocrine sub acțiunea nămolului sapropelic de Techirghiol şi a extractelor sale, Studii şi Cercetări de Balneologie, vol VII, Ed. Medicală Bucureşti, 147-15329.

[37] Marin V., Profir D., Surdu O., Demergian S., Rosoiu N., (2010), Dynamic variation of blood ions during treatment with therapeutic mud, Archives of the Balkan Medical Union, 45, 1, 69-74. 


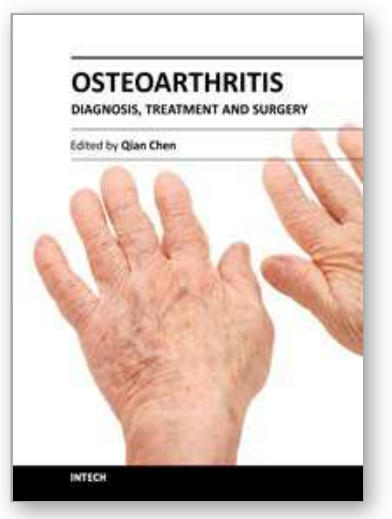

\author{
Osteoarthritis - Diagnosis, Treatment and Surgery \\ Edited by Prof. Qian Chen
}

ISBN 978-953-51-0168-0

Hard cover, 404 pages

Publisher InTech

Published online 02, March, 2012

Published in print edition March, 2012

Osteoarthritis is one of the most debilitating diseases affecting millions of people worldwide. However, there is no FDA approved disease modifying drug specifically for OA. Surgery remains an effective last resort to restore the function of the joints. As the aging populations increase worldwide, the number of OA patients increases dramatically in recent years and is expected to increase in many years to come. This is a book that summarizes recent advance in OA diagnosis, treatment, and surgery. It includes wide ranging topics from the cutting edge gene therapy to alternative medicine. Such multifaceted approaches are necessary to develop novel and effective therapy to cure OA in the future. In this book, different surgical methods are described to restore the function of the joints. In addition, various treatment options are presented, mainly to reduce the pain and enhance the life quality of the OA patients.

\title{
How to reference
}

In order to correctly reference this scholarly work, feel free to copy and paste the following:

Viorica Marin, Olga Surdu, Daniela Profir and Sibel Demirgian (2012). Peloidotherapy in OsteoarthritisModulation of Oxidative Stress, Osteoarthritis - Diagnosis, Treatment and Surgery, Prof. Qian Chen (Ed.), ISBN: 978-953-51-0168-0, InTech, Available from: http://www.intechopen.com/books/osteoarthritis-diagnosistreatment-and-surgery/peloidotherapy-in-osteoarthritis-modulation-of-oxidative-stress

\section{INTECH}

open science | open minds

\author{
InTech Europe \\ University Campus STeP Ri \\ Slavka Krautzeka 83/A \\ 51000 Rijeka, Croatia \\ Phone: +385 (51) 770447 \\ Fax: +385 (51) 686166 \\ www.intechopen.com
}

\author{
InTech China \\ Unit 405, Office Block, Hotel Equatorial Shanghai \\ No.65, Yan An Road (West), Shanghai, 200040, China \\ 中国上海市延安西路65号上海国际贵都大饭店办公楼405单元 \\ Phone: +86-21-62489820 \\ Fax: $+86-21-62489821$
}


(C) 2012 The Author(s). Licensee IntechOpen. This is an open access article distributed under the terms of the Creative Commons Attribution 3.0 License, which permits unrestricted use, distribution, and reproduction in any medium, provided the original work is properly cited. 